\title{
Morphological characteristics of the populations of Coronella austriaca Laurenti, 1768 (Colubridae, Reptilia) on the northern border of its habitat in Russia
}

\author{
S. A. Antipov ${ }^{1}$, A. A. Klenina ${ }^{2}$, I. V. Doronin ${ }^{3 凶}$ \\ ${ }^{1}$ A. M. Nikolsky Herpetological Society \\ 19-10 Heroev prosp., Nizhny Novgorod 603044, Russia \\ ${ }^{2}$ Samara Federal Research Center of $R A S$, \\ Institute of Ecology of the Volga River Basin of Russian Academy of Sciences \\ 10 Komzina St., Togliatti 445003, Russia \\ Zoological Institute, Russian Academy of Sciences \\ 1 Universitetskaya Emb., Saint Petersburg 199034, Russia
}

\section{Article info}

Original Article

https://doi.org/10.18500/1814-6090-2021-21$1-2-3-17$

Received 24 April 2021, revised 6 May 2021 , accepted 8 May 2021

\begin{abstract}
Detailed morphological characteristics of the populations of Coronella austriaca on the northern border of its range, in the Vladimir and Nizhny Novgorod regions, are presented. L.corp. of males and females reaches $543 \mathrm{~mm}$ and $601 \mathrm{~mm}$, respectively. Ventr. is 166-175 and 175-189, respectively, Scd. Is 50-59 and 32-56, Lab. left/right is usually 7/7 (89.7\%), Sublab. is $9 / 9(72.4 \%)$, respectively. A high incidence of asymmetry $(44.4 \%)$ was noted for Temp. I and II rows; of 23 combinations, the most common is the symmetric one $2+3 / 2+3(25.9 \%)$. L.corp./L.cd. limits overlap in $3.1 \%$ of underyearlings and yearlings, and in $1.8 \%$ of adults. Same-sex individuals statistically significantly differ in their meristic characteristics within the studied regions: the females from a locality near the Chucha river differ from the rest ones in $S c d$. and Sublab. left., males differ in $S c d$. and Ventr. $+S c d$.; males also significantly differ in their metric characteristics L.corp., L.cd., L.total.
\end{abstract}

Keywords: Colubridae, Coronella austriaca, pholidosis, morphometry

Acknowledgments: The study was carried out in the framework of the State Theme of the Zoological Institute, Russian Academy of Sciences (No. AAAA-A19-119020590095-9).

For citation: Antipov S. A., Klenina A. A., Doronin I. V. Morphological characteristics of the populations of Coronella austriaca Laurenti, 1768 (Colubridae, Reptilia) on the northern border of its habitat in Russia. Current Studies in Herpetology, 2021, vol. 21, iss. 1-2, pp. 3-17 (in Russian). https://doi.org/10.18500/1814-6090-2021-21-1-2-3-17
This article is an open access article distributed under the terms and conditions of the Creative Commons Attribution 4.0 License
Countries, Dedicated to the 100th Anniversary of the Department of Herpetology at the Zoological Institute of the Russian Academy of Sciences. Saint Petersburg, Zoologicheskij institut RAN Publ., 2019, pp. 27 (in Russian).

Antonyuk E. V. To the question of the northern border of the distribution of the smooth snake Coronella austriaca Laurenti, 1768 in the eastern part of its range. Bulletin of Tambov University, Ser. of Natural and Technical Sciences, 2013, vol. 18, no. 6, pp. 2972-2974 (in Russian).

Bakiev A. G., Poklonceva A. A. Reptiles. In: Mogutova gora: vzaimootnosheniya cheloveka $i$ prirody [Mogutova Gora: The Relationship Between Man and Nature]. Togliatti, Kassandra Publ., 2012, pp. 57-59 (in Russian).

Bannikov A. G., Darevskiy I. S., Ishchenko V. G., Rustamov A. K., Shcherbak N. N. Opredelitel' zemnovodnykh i presmykayushchikhsya fauny SSSR [A Guide of

\footnotetext{
${ }^{\square}$ Corresponding author. Laboratory of Herpetology of Zoological Institute, Russian Academy of Sciences, Russia.

ORCID and e-mail addresses: Sergei A. Antipov: rucfavin@gmail.com; Anastasia A. Klenina: colubrida@yandex.ru; Igor V. Doronin: https:/ orcid.org/0000-0003-1000-3144, Igor.Doronin@zin.ru.
} 
Amphibians and Reptiles of Fauna of USSR]. Moscow, Prosveshchenie Publ., 1977. 415 p. (in Russian).

Garanin V. I. Zemnovodnye $i$ presmykayushchiesya Volzhsko-Kamskogo kraya [Amphibians and Reptiles of the Volga-Kama Region]. Moscow, Nauka Publ., 1983. 175 p. (in Russian).

Dudenkov D. V. Amphibians and Reptiles in the Collection of the Viladimir-Suzdal Museum-Reserve. Catalog. Viadimir, Vladimir-Suzdal Museum-Reserve Publ., 2011. 44 p. (in Russian).

Idrisova L. A. Morfologicheskaya izmenchivost' reptiliy $v$ estestvennykh i laboratornykh usloviyakh: (na primere cheshuychatykh Respubliki Tatarstan) [Morphological Variability of Reptiles in Natural and Laboratory Conditions: (On the Example of the Scaly Republic of Tatarstan)]. Thesis Diss. Cand. Sci. (Biol.). Kazan', 2019. 21 p. (in Russian).

Ivanter E. V. Revising the ecological concept of peripheral populations. Russian Journal of Ecology, 2017, vol. 48, no. 1, pp. 81-85.

Klenina A. A. Uzhovye zmei (Colubridae) Volzhskogo bassejna: morfologiya, pitanie, razmnozhenie [Snakes (Colubridae) of the Volga Basin: Morphology, Nutrition, Reproduction]. Diss. Cand. Sci. (Biol). Togliatti, 2015. 158 p. (in Russian).

Klenina A. A., Bakiev A. G., Pavlov A. V. To the morphology of snakes in the Middle Volga region. Message 1. Determination of the sex of young individuals. University Proceedings. Volga Region. Natural Sciences, 2019, no. 1 (25), pp. 61-71 (in Russian).

Krasnaya kniga Vladimirskoj oblasti [The Red Book of Vladimir Region]. Administration of the Vladimir Region, State Inspectorate for the Protection and Use of Wildlife, State Budgetary Institution "Unified Directorate of Specially Protected Natural Areas of the Vladimir Region"; [O. N Kanishcheva, M. A. Sergeev, eds.]. Tambov, LLC “TPS” Publ., 2018. 432 p. (in Russian).

Krasnaya kniga Nizhegorodskoj oblasti T. 1. Zhivotnye [The Red Book of Nizhny Novgorod Region. Vol. 1. Animals]. Nizhny Novgorod, DECOM Publ., 2014. 446 p. (in Russian).

Kukushkin O. V., Sviridenko E. Yu. Distribution and ecological and morphological features of the smooth snake (Serpentes, Colubridae) in the Crimea. In: Sostoianie prirodnykh kompleksov Krymskogo prirodnogo zapovednika $i$ drugikh zapovednykh territorii Ukrainy, ikh izuchenie i okhrana: materialy nauchnoprakticheskoi konferentsii, posviashch. 80-letiiu Krymskogo prirodnogo zapovednika [State of the Natural Complexes of the Crimean Nature Reserve and Other Protected Areas of Ukraine, Their Study and Protection: Materials of the Scientific and Practical Conference, dedicated to: 80th Anniversary of the Crimean Nature Reserve]. Alushta, 2003, pp. 148-152 (in Russian).

Lazareva O. G. Materials on the ecology of species of amphibians and reptiles included in the Red Book of the Ivanovo region. In: Redkie zhivotnye $i$ griby: materialy po vedeniyu Krasnoj knigi Ivanovskoj oblasti [Rare
Animals and Mushrooms: Materials on Maintaining the Red Book of the Ivanovo Region]. Ivanovo, PressSto Publ., 2012, pp. 39-52 (in Russian).

Lazareva O. G. Amphibians and reptiles in the regional red books of the center of the European part of Russia. In: Nauchno-issledovatel'skaia deiatel'nost' $v$ klassicheskom universitete: traditsii i innovatsii [Elektronnyi resurs]: materialy mezhdunarodnoi nauchnoprakticheskogo festivalia [Research Activity at the Classical University: Traditions and Innovations [Electronic resource]: Materials of the International Scientific and Practical Festival]. Ivanovo, Ivanovskii gosudarstvennyi universitet, 1 electron. wholesale disc (DVD-ROM); 12 cm. System. Requirements: PDF reader 1.5. 2020, pp. 41-44 (in Russian).

Murgraf E. N., Mannapova E. I., Myasnikova N. A., Cheremina O. A., Sherkunov S. A. Materials for the inventory of amphibians and reptiles of the Vladimir region. In: Materialy k kadastru amfibij $i$ reptilij bassejna Srednej Volgi [Materials for the Inventory of Amphibians and Reptiles of the Middle Volga Basin]. Nizhny Novgorod, Ecocenter "Dront" Publ., 2002, pp. 154-166 (in Russian).

Pavlov A. V., Garanin V. I., Bakiev A. G. Smooth snake Coronella austriaca Laurenti, 1768. In: Zmei Volzhsko-Kamskogo kraya [Snakes of the Volga-Kama Region]. Samara, Izdatel'stvo Samarskogo nauchnogo tsentra RAN, 2004, pp. 40-45 (in Russian).

Pestov M. V., Mannapova E. I. Experience of carrying out herpetological works in the Nizhny Novgorod region. Vtoraia konferentsiia gerpetologov Povolzh'ia: tezisy dokladov [Second Conference of Herpetologists of the Volga Region: Abstracts Report]. Togliatti, Institut ekologii Volzhskogo basseina RAN Publ., 1999, pp. 4647 (in Russian).

Pestov M. V., Mannapova E. I., Ushakov V. A., Katunov D. P. Materials for the inventory of amphibians and reptiles of the Nizhny Novgorod region. In: Materialy $k$ kadastru amfibij $i$ reptilij bassejna Srednej Volgi [Materials for the Inventory of Amphibians and Reptiles of the Middle Volga Basin]. Nizhny Novgorod, Ecocenter "Dront" Publ., 2002, pp. 9-72 (in Russian).

Pestov M. V., Mannapova E. I., Ushakov V. A., Katunov D. P., Bakka S. V., Lebedinsky A. A., Turutina L. V. Amphibians and Reptiles of the Nizhny Novgorod Region. Materials for the Inventory. Nizhny Novgorod, Ecocenter "Dront" Publ., 2001. 178 p. (in Russian).

Poklontseva A. A., Chetanov N. A., Bakiev A. G. Comparative morphological analysis of young and adult Smooth snake Coronella austriaca from the Middle Volga Region. Bulletin of Tambov University, Ser. of Natural and Technical Sciences, 2013, vol. 18, no. 6, pp. 3062-3063 (in Russian).

Puzanov I. I., Kozlov V. I., Kiparisov G. P. Zhivotnyi mir Gor'kovskoi oblasti [Animal World of the Gorky Region]. Gor'kii, Gor'kovskoe knizhnoe izdatel'stvo, 1955. 587 p. (in Russian). 
Tabachishin V. G., Shlyakhtin G. V., Zavyalov E. V., Storozhilova D. A., Shepelev I. A. Morphometric differentiation and taxonomic status of reptiles from the Colubridae and Viperidae family. In: Fauna Saratovskoj oblasti [Fauna of the Saratov Region]. Saratov, Izdatel'stvo Saratovskogo universiteta, 1996, vol. 1, no. 2. pp. 39-70 (in Russian).

Tabachishina I. E. Ekologo-morfologicheskii analiz fauny reptilii severa Nizhnego Povolzh'ia [Ecological and Morphological Analysis of the Reptile Fauna of the North of the Lower Volga Region]. Diss. Cand. Sci. (Biol.). Saratov, 2004. 182 p. (in Russian).

Shlyakhtin G. V., Tabachishin V. G., Zavialov E. V., Tabachishina I. E. Zhivotnyi mir Saratovskoi oblasti. Kn. 4. Amfibii $i$ reptilii [Fauna of Saratov Region. Book 4. Amphibians and Reptiles]. Saratov, Izdatel'stvo Saratovskogo universiteta, 2005. 116 p. (in Russian).

Shcherbak N. N. Zemnovodnye $i$ presmykayushchiesya Kryma [Amphibians and Reptiles of the
Crimea. Herpetologia Taurica]. Kiev, Naukova Dumka Publ., 1966. 240 p. (in Russian).

Antipov S. A., Doronin I. V., Milto K. D., Sergeev M. A. Records of amphibians and reptiles in the Vladimir region, Russia. Current Studies in Herpetology, 2018, vol. 18 , iss. $3-4$, pp. $168-179$.

Jablonski D., Nagy Z. T.; Aziz A., Kurtulus O., Kukushkin O. V., Barbod S.-M., Jandzik D. Cryptic diversity in the smooth snake (Coronella austriaca). Amphibia-Reptilia, 2019, vol. 40, pp. 179-192.

Crnobrnja-Isailović J., Ajtic R., Vogrin M., Corti C., Pérez Mellado V., Sá-Sousa P., Cheylan M., Pleguezuelo J., Westerström A., De Haan C. C., Tok V., Borczyk B., Sterijovski B., Schmidt B., Borkin L., Milto K., Golynsky E., Rustamov A., Nuridjanov D., Munkhbayar K., Shestopal A., Litvinchuk S. Coronella austriaca. The IUCN Red List of Threatened Species 2017, 2017, pp. e.T157284A748852. https://dx.doi.org/10.2305/ IUCN.UK.2017-2.RLTS. T157284A748852.en 